\title{
TRANSFORMATIONAL CHANGES IN INTERNATIONAL LABOR MIGRATION UNDER THE INFLUENCE OF GLOBALIZATION
}

\author{
Eteri Rubinskaya ${ }^{1}$
}

\begin{abstract}
Under the conditions of globalization the role and the place of international migration within the system of the world economy are experiencing many changes. International labor migration today is characterized not as much by enlargement or by the increased number of countries engaged in the international migratory processes, but more by changes in the structure and dynamics of migration flows which, in their turn, are one of the manifestations of the changing demands of countries at their post-industrial stage of development. In this article, we make an attempt to determine the chronology of development for the process of globalization of the world's economy in parallel to also determining the specificity of international migration at each of these stages. We have found, inter alia, that international migration is a large-scale, multifactor and highly dynamic socioeconomic phenomenon and is also a vital factor of influence upon the demographic development and economic growth of countries since it promotes and supports the ongoing process of globalization.
\end{abstract}

JEL Classification Numbers: F22; DOI: http://dx.doi.org/10.12955/cbup.v6.1191

Keywords: globalization, transformational changes, international labor migration, scientific and technical revolution, highly qualified professionals

\section{Introduction}

Globalization as a qualitatively new stage of internationalization means not only wider and deeper forms of various connections and a growing interdependence of countries worldwide, but it is also a shift in the direction to the formation of a true world economy. Globalization boosts all processes in the world economy, including the process of international migration of the labor force.

Scientific discussion concerning the influence of globalization on international migration of populations started back in the late 1980s and became much more active during the 1990s, continuing till now (Rubinskaya, 2017). Mutual correlation between globalization and migration has been quite fully revealed in the studies by S. Castles (Castles and Mille, 2003), P. Stalker (Stalker, 2000), D. Massey (Massey and Taylor, 2004), R.J. Simon (Simon, 2008), Findlay A. (Findlay, 2001), Ivakhniouk I. (Ivakhniouk, 2016) and others. All of these authors have carried out quite substantial analyses of the migration trends in various countries and regions and all came to a very much similar conclusion that massive flows of labor migration are always in direct dependence on economic globalization and the development of the world market. Today's key features of international migration of populations (ever-growing volumes of relocation, structural and geographical shifts) are objectively predetermined by qualitative changes taking place today in the world economy due to the impact of the globalization processes.

The aim of this research is the analysis of qualitative and quantitative changes in the migration processes under the conditions of globalization of the world's economy. The author offers their own division of the process of globalization of the world's economy into periods, revealing also the key features of international labor migration at each of these periods.

\section{Stages of globalization changes and international migration}

Intensified globalization of the world economy along with other trends impacting the whole system, including international migration of the labor force, started after the second World War. The author can outline three stages in the course of the evolution of globalization:

- The first stage - from the second half of the 1940s till late 1960s;

- The second stage - 1970s-1980s;

- And the third stage - from the 1990s till present.

The key criterion for the transition from one stage to another is the degree of globalization changes in the world economy under the impact of development of production forces and profound social and political transformations, both leading to serious qualitative changes in the processes of international migration of the labor force (Rubinskaya, 2015).

Determinants of the first stage in globalization was the scientific and technical revolution and the collapse of the colonial system.

\footnotetext{
${ }^{1}$ Russian Presidential Academy of National Economy and Public Administration (RANEPA), Affiliation ID: 60016781, eteri-rubinskaya@mail.ru
} 
The scientific and technical revolution provoked a new wave in international migration of the labor force since, on the one hand, capitalistic countries used quite successfully the latest achievement of this revolution, thus expanding the demand for labor resources, and on the other hand - the revolution also contributed to the growing inequality in the economic development of the countries worldwide. Thus, the populations of third world countries were basically pushed out of their countries in search of work. Scientific and technical progress has also transformed migration flows qualitatively: the share of well-educated and highly qualified migrants started to increase. The notion "brain drain" was first used back in the early 1950s, in one of the reports of the Royal Society in London, dedicated to the massive outflow of scientists from the United Kingdom to the USA and Canada. This process became even more intense during the 1960s when scientists and engineers started to emigrate to the US from not only the UK but also many other countries worldwide (Dickson, 1985).

Another important factor of qualitative changes in the world economy at the first stage of globalization was the fight of colonial (or dependent in a similar way) countries for their independence which eventually led to the full collapse of the world colonial system. Political sovereignty of these countries did not automatically mean economic prosperity and/or increase in their quality of life however, their independence provided the citizens of these countries with new opportunities for migration - from former colonies to metropolises.

This first stage in globalization had another key feature - development of intracontinental migration, which became especially meaningful for post-war Europe. Restoration of the nearly fully destroyed industries all over Europe would have been impossible by means of only internal/national labor resources. Thus, attracting labor forces from other countries became a vital necessity for all these countries. The key countries in terms of immigration were then Germany (its western part), France, Belgium, Switzerland and some other states of western and Nordic Europe. This resulted in the countries of emigration becoming less economically developed European countries, with higher rates of natural population growth and a larger share of the non-qualified labor force (Turkey, Italy, Greece, Spain, Portugal and Yugoslavia).

During the second stage of globalization development, many processes within the world economy were developing under the impact of both technological and information revolutions. Other important events of this period concerned transformational changes in Eastern Europe and the opening of China to the West (the so-called policy of "reforms and openness"). All these processes and events contributed to the expansion of the world market space and also - to the complication of interrelations within the world economy.

New opportunities, provided by the technological and information revolutions of the 1970s-1980s did not remove the contradiction between economically developed countries, and those lagging behind. As it was noted by Manuel Castells (Castells, 2000), differences in the time of access to technological capacities for various people, countries and regions became one of the most critical sources of inequality in the contemporary world. A symbolic peak moment in this process was the threat of total exclusion of whole national economies or even continents (Africa, for example) from the world information system, which meant they would also be excluded from the world system of labor distribution. The major consequence of this is the massive migration from Global South to Global North overall. The situation worsened even more because this brain drain concerned mostly very poor countries. For instance, Ghana lost about $60 \%$ of all its medical doctors, who got their degrees during the 1980s. Overall, more than 600 ths highly qualified professionals left the African continent during the second half of the 1980s (Lowell, Findlay, 2001).

Despite the slowing down of economic growth in Europe, the number of emigrants to this region continued to grow, partially due to reunification of families and the still ongoing postcolonial immigration (the process of decolonization and the corresponding return to the UK, France, Netherlands and Belgium). Besides that, integration processes which were taking place in Europe during the same time, also contributed to the intensification of migration flows, in this case - through high mobility between European countries.

The key feature of this stage is the strengthening role of international organizations, transnational corporations and other forms of states and integration of businesses in the attempt to regulate the international migration of labor force. 
The third stage of globalization concerns the whole world economy. Two major factors were behind this: first of all, the collapse of the Soviet Union and all further transformational changes on its former territories; and secondly, the growing speed of technological and information development. Russia, along with all other post-Soviet and post-socialistic countries of Eastern Europe, got actively engaged in migration processes. The collapse of the USSR alone increased the number of international migrants by more than 27 million people. Starting from the 1990s Russia has been steadily in the top-3 of the world by the number of international migrants (Rubinskaya, 2014).

Rapid development of new technologies has also contributed to the quicker relocation of capital, commodities, labor forces, services and information between the countries and continents, thus only increasing globalization interdependence. The processes of integration and trans-nationalization have also become much more active. As a result, many industrially developed countries moved to the next stage in their development - the post-industrial stage, which is based on the production forces of a new generation, united by the global information and technological systems.

The key resources of development today are, first of all, people and their knowledge, their work experience and also their strive to update their knowledge. Migration flows between the countries are becoming more and more qualified. Transnational companies become quite important actors in migration of these highly qualified professionals. According to the International Organization for Migration reports, $22 \%$ of all labor migrants belong to the category of highly qualified personnel and in the developed countries this share is even larger than the world average (World migration report 2013, 2012). Many countries today focus their migration policies on the attraction of these highly qualified professionals, and this concerns not only already developed countries but also developing economics, including China, Brazil, Argentina etc. The economic role of international migration of the labor force is only growing, thus international migration becomes an important factor of the dynamic development of the global economy.

Let me formalize in a logical table the above analyzed stages of the process of globalization.

Table 1: Brief description of the stages of globalization changes

\begin{tabular}{|c|c|c|c|c|}
\hline Stages & $\begin{array}{l}\text { Factors contributing to } \\
\text { globalization }\end{array}$ & $\begin{array}{l}\text { Sphere of } \\
\text { cover }\end{array}$ & Impact on the global economy & $\begin{array}{l}\text { Number of } \\
\text { international } \\
\text { migrants }\end{array}$ \\
\hline $\begin{array}{l}\text { First } \\
\text { stage }\end{array}$ & $\begin{array}{l}\text { scientific \& technical } \\
\text { revolution; } \\
\text { collapse of the colonial } \\
\text { system }\end{array}$ & $\begin{array}{l}\text { capitalistic } \\
\text { countries; } \\
\text { postcolonial } \\
\text { countries }\end{array}$ & $\begin{array}{l}\text { Deepening of interstate and } \\
\text { industrial interrelations; } \\
\text { formation of international regional } \\
\text { economic unions }\end{array}$ & $\begin{array}{l}1960 \mathrm{~s}- \\
77 \mathrm{mln} \text { people }\end{array}$ \\
\hline $\begin{array}{l}\text { Second } \\
\text { stage }\end{array}$ & $\begin{array}{l}\text { technological and information } \\
\text { revolution; } \\
\text { start of transformational } \\
\text { changes in the socialist } \\
\text { countries }\end{array}$ & $\begin{array}{l}\text { market } \\
\text { economies }\end{array}$ & $\begin{array}{l}\text { strengthening roles of international } \\
\text { organizations, transnational } \\
\text { corporations; } \\
\text { movement towards the formation of } \\
\text { a world economy as a whole }\end{array}$ & $\begin{array}{l}1970 \mathrm{~s}- \\
84 \mathrm{mln} \text { people } \\
1980 \mathrm{~s}- \\
102 \mathrm{mln} \text { people }\end{array}$ \\
\hline $\begin{array}{l}\text { Third } \\
\text { stage }\end{array}$ & $\begin{array}{l}\text { the collapse of the Soviet } \\
\text { Union; } \\
\text { growing speed of } \\
\text { technological and information } \\
\text { development }\end{array}$ & $\begin{array}{l}\text { the whole } \\
\text { world }\end{array}$ & $\begin{array}{l}\text { Formation of global markets for } \\
\text { goods, capital, technology and labor } \\
\text { force }\end{array}$ & $\begin{array}{l}1990 \mathrm{~s}- \\
153 \mathrm{mln} \text { people } \\
2017 \mathrm{~s}- \\
258 \mathrm{mln} \text { people }\end{array}$ \\
\hline
\end{tabular}

Source: Author, with statistic from the United Nation, Population Division, Department of Economic and Social Affairs

http://www.un.org/en/development/desa/population/migration/data/estimates2/estimates17.shtml

\section{Dynamics of the migration processes in the context of globalization}

The development of globalization trends at the end of millenniums had impacts on international migration of populations, which has become even more global, now covering nearly all regions and countries worldwide. Since the 1960 till today, the overall number of international migrants grew more 
than 3,3 times. Despite the fact that the share of migrants in the population did not change that radically, quite significant shifts are observed in terms of destination regions. Thus, if back in 1960 the share of migrants in the European population was about 3,4\%, then in 2017 it would have already reached 10,5\%. Similar trends are observed in North America, Australia and Oceania (table 2).

Table 2: Regional distribution of international migrants in 1960 and 2017

\begin{tabular}{|c|c|c|c|c|c|c|}
\hline \multirow[t]{2}{*}{ Regions } & \multicolumn{3}{|l|}{1960} & \multicolumn{3}{|l|}{2017} \\
\hline & $\begin{array}{l}\text { Number of } \\
\text { international } \\
\text { migrants, } \\
\text { mln people }\end{array}$ & $\begin{array}{l}\text { Share of the } \\
\text { world number of } \\
\text { migrants, \% }\end{array}$ & $\begin{array}{l}\text { Share of the } \\
\text { region } \\
\text { population, \% }\end{array}$ & $\begin{array}{l}\text { Number of } \\
\text { international } \\
\text { migrants, mln } \\
\text { people }\end{array}$ & \begin{tabular}{|l} 
Share of the \\
world number \\
of migrants, $\%$
\end{tabular} & $\begin{array}{l}\text { Share of the } \\
\text { regional } \\
\text { population, } \%\end{array}$ \\
\hline World & 77,1 & 100 & 2,7 & 257,7 & 100 & 3,4 \\
\hline Africa & 9,2 & 11,9 & 3,2 & 24,6 & 8 & 2 \\
\hline Asia & 28,5 & 37 & 1,7 & 79,6 & 30,6 & 1,8 \\
\hline Europe & 14,6 & 18,9 & 3,4 & 77,9 & 31,3 & 10,5 \\
\hline Latin America & 6,1 & 8 & 2,8 & 9,5 & 3,7 & 1,5 \\
\hline North America & 13,6 & 17,6 & 6,7 & 57,7 & 23 & 16 \\
\hline $\begin{array}{l}\text { Australia and } \\
\text { Oceania }\end{array}$ & 2,1 & 2,8 & 13,5 & 8,4 & 3,4 & 20,7 \\
\hline Former USSR & 2,9 & 3,8 & 1,4 & & & \\
\hline
\end{tabular}

Generally speaking, if during the 1960s the share of migration in the most developed countries was $3,6 \%$ of the population - then in 2017 it was already over 11,6\% (table 3 ). This shows a threefold increase, while in the least developed countries the situation is almost the complete opposite - the number of international migrants decreased from $2,1 \%$ to $1,8 \%$.

Table 3: The share of international migrants in the total population for 1960-2017

\begin{tabular}{|l|l|l|l|l|l|l|}
\hline & 1960 & 1970 & 1980 & 1990 & 2000 & 2017 \\
\hline World & 2,6 & 2,3 & 2,3 & 2,8 & 2,8 & 3,4 \\
\hline $\begin{array}{l}\text { The most developed } \\
\text { countries }\end{array}$ & 3,6 & 3,9 & 4,5 & 7,4 & 8,7 & 11,6 \\
\hline $\begin{array}{l}\text { The least developed } \\
\text { countries }\end{array}$ & 2,1 & 1,6 & 1,6 & 1,6 & 1,4 & 1,8 \\
\hline $\begin{array}{l}\text { Source: The United Nation, Population Division, Department of Economic and Social Affairs } \\
\text { http://www.un.org/en/development/desa/population/migration/data/estimates2/estimates17.shtml }\end{array}$ \\
\hline
\end{tabular}

Migration results in the overall growth of labor resources in countries migrants move. In Western Europe laborers of foreign origin comprise around $10-15 \%$ of the overall volume of the labor force, while in Australia, Canada and the USA their number is around $18 \%$. Overall, countries with the highest income levels accept around $75 \%$ of all labor migrants in the world (World migration report 2017, 2018). Migration flows today are directed in the same way, just like decades ago - from the least developed economies to the most developed ones. Thus, the number of migrants from the Global South grew, during the period of 2000 to 2017 , from $67 \%$ of all international migrants to $72 \%$.

The demographic factor has quite a strong influence on the world dynamics of migration processes. In the period of 1960 till 2017, the population of the planet overall increased more than twice, thus reaching a number of around 7,5 billion people. The overall growth of world population is to a larger extent explained by the actively growing population numbers in Asia, Africa and Latin America. Their joint share in the world population is over $85 \%$. 
According to UN forecasts, the rate of world population growth will somewhat slowdown in the coming decade however, the overall number of people on this planet will reach 9,6 billion by 2060 . And this increase will take place, just as now, due to population growth in developing countries. This in turn means that a geographical misbalance of labor resources will only increase.

Scientific achievements in the medical field have led to lower mortality rates and longer life expectancy. Consequently, today we observe an overall aging of the population, smaller share of working-age population resulting in a heavier load on the working population. This problem concerns the developed countries most of all. On the other hand, developing economies, such as Brazil, Mexico or Indonesia, have much a larger share of a young population. At the same time, not all developing countries would be able to use this advantage of a favorable demographic situation. Only those where the population has a quite high level of education and professional skills will be able to make the most of their larger young population.

According to some expert estimations (International migration and development, 2006), in the coming 25 years, the efficient functioning of economies such as the US, EU and Canada would require at least 100 million highly qualified specialists of various fields. The job requirements of these specialists would only grow in time, since apart from standard professional skills, they would need to have higher academic standing and be proficient in STEM, at least to some extent. Solving this task without attracting foreign qualified human resources would be difficult if not impossible. Therefore, all issues related to migration processes would only gain more and more importance.

\section{Conclusion}

The global nature of world economic development and the growing interdependence of countries on the one hand, as well as differences in the levels of economic, social, cultural and political development with all their contradictions on the other, predetermine today the combination of causes behind international migration along with a variety of factors influencing its dynamics. The economic development of countries eventually defines the geographical vectors of migration flows of the international labor force today.

Globalization as a macro factor of the development of the world's economy has a rather ambiguous influence on the international migration of populations overall, especially on work-related migration. Globalization means that nearly all countries today are engaged in international labor migration and this in turn forms the global demand and supply of labor forces. The international labor migration provokes further increases in the volumes of labor migration, and also further structural and geographical changes in migration. In such a way globalization becomes the most important factor in the development of the world labor market. At the same time, the role and the place of migration of the international labor force within the world economic system are also changing due to globalization: migration becomes yet another means to promote the globalization of countries and regions even further, and it also becomes a vital factor in demographic development and economic growth worldwide.

\section{References}

Castells M. (2000). The Information Age: Economy, Society and Culture / Trans. from English. under scientific. Ed. by O. I. Shkaratan. Moscow, Publ. House of Higher School of Economics. p.53.

Castles S., Davidson A. (2000) Citizenship and Migration: Globalization and the Politics of Belonging. London : Macmillan. Castles S., Miller M. (2003) The Age of Migration: International Population Movements in the Modern World. 3d ed. NY: Palgrave Macraillan.

Czaika M., De Haas H. (2014) The Globalization of Migration: Has the World Become More Migratory?// International Migration Review 48(2).

Dickson D. (1985) Britain increases science spending / D. Dickson // Science. - Wash. - Dec. 6. - Vol.230, N 4730.

Findlay A. (2001) International Migration and Globalization: An Investigation of Migration Systems in Pacific Asia, with Particular Reference to Hong Kong // International Migration into the 21st Century / Ed. by M. A. B. Siddique. Cheltenham, UK : Edward Elgar.

International migration and development (2006, May 18)// Report of the Secretary-General / UNGA.

Ivakhniouk I. (2016), The development of migration theory in the context of globalization// Vek globalizatsii. №1-2

Iontsev V., Aleshkovsky I. (2008) Tendencies of the international migration in the globalized world // Vek globalizatsii. 2008. №2

Iontsev V. A (2006). International migration and globalization of the world economy // International Economics, №2, 3 
Lowell B., Findlay A. (2001) Migration of highly skilled persons from developing countries: impact and policy responses. International labor office. p. 5

Massey D. and Taylor J.E. (2004) International Migration: Prospects and Policies In A Global Market, edited by D.Massey and J.E.Taylor. New York Oxford University Press.

Rubinskaya E. (2015) Development of international labor migration in the dynamics of globalization processes// Journal of Economic Regulation. №1, p. 84.

Rubinskaya E. (2015) "Historical and methodological approaches to the analysis of international labor migration in a globalizing world economy"/ in international collective monograph "Urbanization and Migration as Factors Affecting Global Economic Development" (IGI - publisher, USA)

Rubinskaya E. (2017) Globalization as a factor for national migration policy modernizing (the case of Russia)// The EUrASEANs, №3

Rubinskaya E. (2014). International labor migration: methodology and practice: a monograph. - Rostov N / Univ YURIU branch RANHiGS. p. 250.

Simon G. (2008) La planete niigratoire dans la mondialisation. Paris: Armand Colin.

Solimano A. (2010) International Migration in the Age of Crisis and Globalization: Historical and Recent Experiences. Cambridge: Cambridge University Press.

Stalker P. (2000) Workers Without Frontiers. The Impact of Globalization on International Migration London: Lynne Rienner Publishers, Boulder (Co.).

World migration report 2013 (2012). International Organization for Migration (IOM). Retrieved from https://publications.iom.int/system/files/pdf/wmr2013_en.pdf.

World migration report 2018 (2017). International Organization for Migration (IOM). Retrieved from https://publications.iom.int/system/files/pdf/wmr_2018_en.pdf.

United Nation, Population Division, Department of Economic and Social Affairs. Retrieved from http://www.un.org/en/development/desa/population/migration/data/estimates2/estimates17.shtml 